\title{
The Influence of Celebgram on Online Purchasing Decision
}

\author{
Heny Hendrayati, Vanessa Gaffar, Dea Sintia Dwiyanty \\ Faculty of Economics and Business Education \\ Universitas Pendidikan Indonesia \\ Bandung, Indonesia \\ henyhendrayati@upi.edu
}

\begin{abstract}
Social media Instagram having a growth increasing and very high in Indonesia. The function of social media Instagram has expanded, which is for transaction online too. This makes phenomenon online purchasing decision so familiar and so many online shop utilize this phenomenon. Because so much new online shop, it makes Walk in summer should be more creative and innovative in marketing their product, like used Celebgram (Celebrity Endorser on Instagram). This research aims to find a representation on Celebgram as company promotion media and purchase decisions as well as the influence of Celebgram to online purchasing decision. This research uses purposive sampling, because respondents must be conformed the requirement. The results of this research that used Celebgram as a media promotion has positive influence on purchasing decisions of Walk in Summer, and the results of the correlation calculations show a positive correlation with a lower classification.
\end{abstract}

Keywords-Promotion with Social Media, Celebrity Endorser on Instagram, Online Purchasing Decision

\section{INTRODUCTION}

Total users Internet in Indonesia according to survey on Association organizer service Internet Indonesia (APJII), for the period time 16 year (2000-2015) increase from 2 million into 139 million users. The development of the Internet is supported with high mobility to access so much easier and faster. High mobility gave birth to a social media era, where social media is regarded as the most effective means of delivering information. The community take advantage of this phenomenon in many everyday activities [1]. According to the IBM Global CMO Study, social media can create a transaction online [2].

Along with the development of the use of social media as a land for online transactions, make one of the companies that manufacture footwear or shoes, Walk in Summer take advantage of these opportunities. Company promotion through social media, one that is Instagram. This is because, Instagram experience rapid growth in Indonesia and have more users [3] Indonesia including third country with Instagram users in the world [4]. Instagram users who have dramatically increased, shaping the diversity of behavior, which is nothing to look at the online shop, public figures, new places, culinary, etc. Instagram user behavior that is viewed online shop included in the high category. However, it turns out the other data states that the user is only interested to see it, because the purchasing power is still low even lower than the level of purchasing power often or never buy the product at the online shop which was follow [5]. This shows that potential customers do not believe in the online shop is currently favored by netizens in Indonesia. In addition, the number of competitors businesses that sell the same products to the enterprise so that prospective customers are likely to have a low level of purchasing power because they can not find the hallmark of products that comply with her wishes. This phenomenon can certainly decrease the company's sales Walk in Summer. The author interviewed one of the company's staff in the marketing.

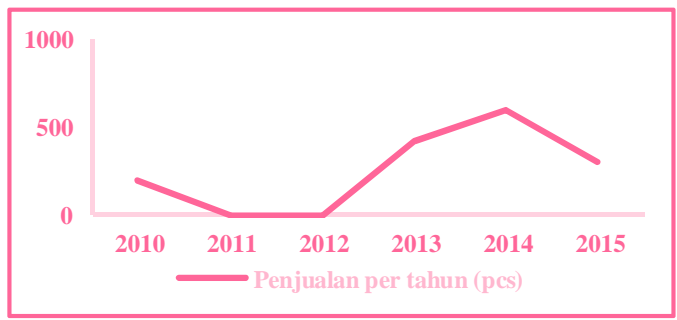

Fig. 1. Growth Walk-in sales Summer

Source: Marketing Walk in Summer, 2015

The graph in Figure 1 illustrates that the purchasing decisions of consumers to choose Walk in Summer is still so low. Purchasing decisions affect the company's sales, because consumers purchasing decisions determine consumer buying decisions to a product she likes. The decline in sales of the company and its development is unstable, making it shall determine media strategies appropriate promotion in marketing their products. The strategy is right, it will make the sales growth improved and increased. Media promotion of the company through advertising on social media Instagram has not been able to provide the impact of increased sales stable, and therefore could be by means of specific interaction of a celebrity, which is seen as an individual who favored by the people and has the creative excellence attractive that distinguishes it from other individuals.

At the national and international level, through the marketing of celebrity can be an opportunity to have a major impact on the company. Celebrities make the marketers argue that they will give a great influence to their own fans. Nowadays, celebrities are not just people who are admired, but could be the one that can be emulated by others. This is 
especially true among young people, where they can now easily view and follow the style of their favorite celebrities on social media such as Twitter, Facebook and Instagram [6].

Celebrities are considered informative to the trend which then led activities on the products they use to the public through social media Instagram. This gave rise celebgram is an abbreviation of celebrity endorser on Instagram. Celebgram be one of the promotional media advertising strategy using social media celebrity endorser on Instagram that are favored by many online shop in Indonesia at the present time. Their celebgram, in addition to providing information and recommendations also very easy for Instagram users who follow celebrity to a product endorser in determining alternatives and offers the best price.

\section{LITERATURE REVIEW}

\section{A. Celebgram (Celebrity Endorser on Instagram)}

Celebrities is an essential component to attract public attention to the product and brand. Celebrities should have a high recognition, positive effect, and high precision products. Celebrities can give more strategic role for their brand, not only advertise products, but also can design, positioning and selling goods or services [7].

Celebrity endorser on Instagram or we can called as Celebgram are a new celebrity who began to emerge as the owner of online shop on Instagram using them as models of their products [6]. Endorser on social media Instagram is different with endorser in conventional media, because on Instagram, anyone can become endorser or so-called Celebgram (Celebrity Endorser on Instagram). Whereas in conventional media, celebrity endorsements who have been known by many people like actress or actor. Celebgram appeared because the influence of social media users are began to follow the Instagram accounts in accordance with her wishes [8].

Celebrity endorser on Instagram is one of strategy aims to increase the volume of sales by grabbing the attention of consumers to consumers recognize and are interested in and then decide to buy the products of a company. Celebrity endorser on Instagram or part of the endorser is composed of two attributes main credibility and attractiveness, or we can used acronym called the model TEARS, where confidence (trustworthiness), and skills (expertise) are the two dimensions of credibility (credibility), while the attractiveness of appearance (physical attractiveness), honor (respect), and matches to the target audience (similarity) is a component of interest (attractiveness) [9].

\section{B. Purchasing Decision}

Purchasing decisions is an essential part of consumer behavior that lead to the purchase of products and services. Purchasing decisions is one part of consumer behavior. Purchasing decisions usually to choose between 2 options in which the decision was made in order to meet their needs as well as consumer response to the problem.
Purchasing decision of an evaluation phase for the consumer to establish selection among the existing brand and formed the intention to buy the brand most preferred [7]. Purchasing decisions made by consumers certainly effect on the company, because the purchase decision, determine consumers to buy products from a company or not.

Purchasing decision does not happen because of some subdecisions that assist consumers in making purchasing decisions. There are dimension in the purchasing decision [10]:

a. Selection of products: Consumers determine which products will be purchased, which according to his choice.

b. Selection of Brand: Consumers must decide which brand they will use.

c. Selection of purchasing channel: Consumers should decide on the dealer where they'll arrive.

d. Determination of the number of purchases: Consumers can decide how much he will buy / wear a product / service of the company.

e. The timing of purchases: The consumer's decision to buy or use the product will vary and are not necessarily.

f. Determination of the payment method: Consumer decision in deciding their purchases using payment types will vary. Such as, credit cards, vouchers, cash, and debit cards.

Based on the description of the framework, the research paradigm can be determined as follows:
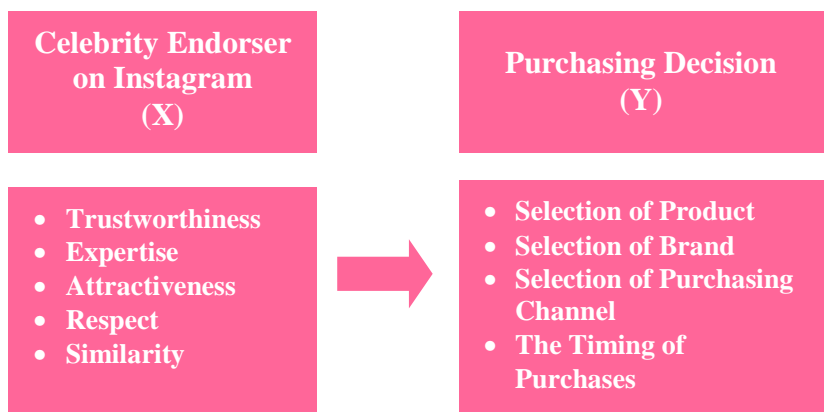

Fig. 2. Paradigm Research

Based on research paradigms, hypotheses of this study is "there is an influence of celebrity endorser on Instagram on purchase decisions."

\section{RESEARCH METHOD}

The approach used in this study is quantitative. In this study, variables will be research use descriptive and verification. Descriptive research can be obtained, describe of celebrity endorser on Instagram and also a description of purchasing decision. Verification studies basically wanted to test the correctness of the data obtained in the field that has been collected. This study examines the relationship between celebrity endorser on Instagram (X) with the purchasing decision (Y). 


\section{Axumess PRESS}

Based on the types of research, the research method is explanatory survey, because this methods explains comparison variable used hypothesis testing, survey is taking samples from a population and use questionnaire to collecting data. Researcher can get the opinion from respondents, because they are go into the field.

In this study, the target population are respondents who have bought products online shoe Walk in Summer. Total population is taken is the number of followers on social media Instagram, as many as 51.400 respondents.

\section{ŠUUimér}

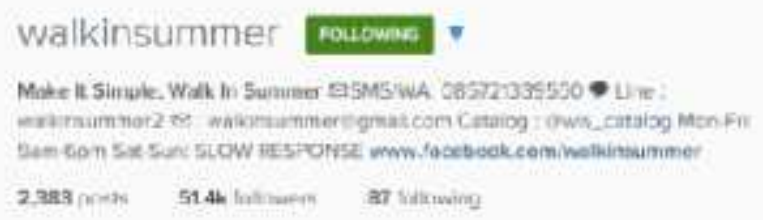

Fig. 3. Screenshot Number of Followers Walk in Summer (December 15, 2015, 06:52) [11]

In determining the number of samples, researchers with the calculation formula Slovin, then the samples obtained are as many as 400 respondents. Sample selection technique used is purposive sampling, because the sample as respondents deliberately chosen to match the characteristics that have been determined to reflect the population.

Validity coefficients on a scale of celebrity endorser on Instagram ranged from 0.501 to 0.868 with a significance level of 0.374 rtabel to be valid. Validity coefficients perception scale purchasing decisions ranged from 0.376 to 0.759 with a significance level of 0.374 which is in the valid criteria. The coefficient of reliability scale celebrity endorser on Instagram $(\mathrm{X})$, and the purchase decision $(\mathrm{Y})$ respectively amounted to 0.908 and 0.744 proved to be greater than the minimum reliability Cronbach's Alpha amounting to 0,700. Therefore, the overall statement items contained in the questionnaire studies have been reliable in accordance with the reliability test.

\section{RESULT AND DISCUSS}

Test statistic in this study used a simple linear regression analysis. The data used as the independent variable (X) is a celebrity endorser on Instagram and the dependent variable (Y) is the company's purchasing decisions on shoes Walk in Summer.

\section{A. Normality Test Results}

Normality test on the regression model is a test used to analyze the data and determine whether the data independent and dependent variables of a study consisting of grains questions normal distribution or not. In this research will be the distribution of the data celebrity endorser on Instagram (independent variable) and purchasing decisions (dependent variable). To detect normality, use normal probability plots, can be seen in the following figure:
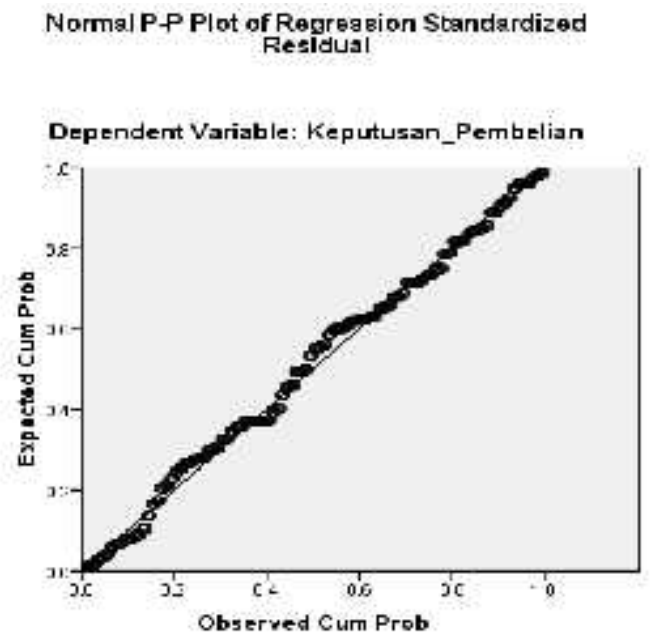

Fig. 4. Normality test

Source: Data Processing Using SPSS 17.0, 2016

Based on Figure 4, it can be concluded that the data is spread around the diagonal line from the lower left to the upper right, then the regression model showed that normalias requirements are met.

\section{B. Correlation coefficient}

The correlation coefficient ( $r$ ) indicates the degree of correlation / relationship between the independent variable (X) and the dependent variable (Y). Correlation of the two variables are analyzed using Pearson Correlation in SPSS 17.0 for Windows. The following correlation analysis of this study are presented in Table I as follows:

TABLE I. OUTPUT CORRELATION

\begin{tabular}{|c|l|c|c|}
\hline \multirow{2}{*}{ Correlations } \\
\hline \multirow{2}{*}{$\begin{array}{c}\text { Pearson } \\
\text { Correlation }\end{array}$} & Purchasing decision & $\begin{array}{c}\text { Purchasing } \\
\text { decision }\end{array}$ & $\begin{array}{c}\text { Celebrity } \\
\text { Endorser on } \\
\text { Instagram }\end{array}$ \\
\cline { 2 - 4 } & Celebrity Endorser on Instagram & 1.000 & .527 \\
\hline \multirow{2}{*}{ Sig.(1-tailed) } & Purchasing decision &. & 1.000 \\
\cline { 2 - 4 } & Celebrity Endorser on Instagram & .000 & .000 \\
\hline \multirow{2}{*}{$\mathbf{N}$} & Purchasing decision & 400 &. \\
\cline { 2 - 4 } & Celebrity Endorser on Instagram & 400 & 400 \\
\hline
\end{tabular}

Source: Data Processing Using SPSS 17.0, 2016

The correlation value between the purchasing decision with celebrity endorser on Instagram amounted to 0.527 and the significance of 0.000 . The value of significance $<0.05, \mathrm{H} 0$ is rejected and $\mathrm{H} 1$ accepted. Thus, it can be said that there is a significant relationship between celebrity endorser on Instagram with purchasing decisions.

Based on the guidelines for the interpretation of the correlation value, the correlation value is in the interval from 0.400 to $0.599,0.527$ belonging to the moderate level of correlation. 


\section{Simple Regression Analysis}

The study consists of one independent variable so that the regression analysis technique used is a simple linear regression (simple), simple regression analysis is used to determine how the dependent variable (Y) purchasing decisions can be predicted by the independent variable $(\mathrm{X})$ celebrity endorser on Instagram or predictor in individually. the following Table II which describes the results of a regression analysis of the data processing SPSS 17.0 for Windows:

TABLE II. OUTPUT COEFFICIENT OF REGRESSION

Coefficients $^{\mathrm{a}}$

\begin{tabular}{|c|c|c|c|c|c|c|}
\hline & \multirow[t]{2}{*}{ Model } & \multicolumn{2}{|c|}{$\begin{array}{l}\text { Unstandardized } \\
\text { Coefficients }\end{array}$} & \multirow{2}{*}{\begin{tabular}{|c|} 
Standardized \\
Coefficients
\end{tabular}} & \multirow[t]{2}{*}{$\mathbf{T}$} & \multirow[t]{2}{*}{ Sig. } \\
\hline & & B & Std. Error & & & \\
\hline \multirow[b]{2}{*}{1} & (Constant) & 10.444 & 1.054 & & 9.909 & .000 \\
\hline & $\begin{array}{l}\text { Celebrity Endorser } \\
\text { on Instagram }\end{array}$ & .343 & .028 & .527 & 12.369 & .000 \\
\hline
\end{tabular}

a. Dependent Variable: Purchasing decision

Source: Data Processing Using SPSS 17.0, 2016

From the table, we can get the equation of this research, that is:

$$
\mathrm{Y}=10,444+0,343 \mathrm{X}
$$

From the equation, the constant is 10,444 which is show that if there is not celebrity endorser on Instagram, purchasing decision for Walk in summer is 10,444 . While, coefficient regression of celebrity endorser on Instagram is 0,343 , it means if celebrity endorser on Instagram increasing or just one unit, purchasing decision will increase too by 0,343 . For calculate the influence of celebrity endorser on Instagram to purchasing decision used coefficient determination, that is:

$$
\begin{aligned}
\mathrm{KD} & =\mathrm{r} 2 \times 100 \% \\
& =(0,527) 2 \times 100 \% \\
& =27,8 \%
\end{aligned}
$$

The result from data processing show that celebrity endorser on Instagram have a positive influence to purchasing decision shoe Walk in Summer, that is $27,8 \%$, and $72,2 \%$ from other things not examined by the authors.

\section{Hypothesis Testing}

Hypothesis testing used to know the level signification of coefficient correlate between independent variable and dependent variable and the hypothesis testing for this study is testing $\mathrm{t}$, that is:

TABLE III. The SignificANT VALUE of T TeSt Coefficients $^{\mathbf{a}}$

\begin{tabular}{|l|l|c|c|c|c|c|}
\hline \multicolumn{2}{|c}{ Model } & \multicolumn{2}{|c|}{$\begin{array}{c}\text { Unstandardized } \\
\text { Coefficients }\end{array}$} & $\begin{array}{c}\text { Standardized } \\
\text { Coefficients }\end{array}$ & \multirow{2}{*}{ T } & \multirow{2}{*}{ Sig. } \\
\cline { 1 - 6 } & B & Std. Error & Beta & & \\
\hline 1 & \begin{tabular}{l} 
(Constant) \\
\cline { 2 - 6 }
\end{tabular} & 10.444 & 1.054 & & 9.909 & .000 \\
\hline & $\begin{array}{l}\text { Celebrity Endorser } \\
\text { on Instagram }\end{array}$ & .343 & .028 & .527 & 12.369 & .000 \\
\hline
\end{tabular}

a. Dependent Variable: Purchasing decision
To test the hypothesis of partial comparing $\mathrm{t}$ arithmetic with $\mathrm{t}$ table $=1.649 \mathrm{t}$ is generated for the variable celebrity endorser on Instagram is 12.369 , then t table (12.369> 1.649), meaning that there is the influence of celebrity endorser on Instagram (X) on purchasing decisions (Y) on Walk in Summer. Variable probability value on Instagram celebrity endorser 0.05 is well below 0,000 so that through this method

is also found at a significance level of $5 \%$ variable on Instagram celebrity endorser positive and significant impact on the purchase decision variables Walk in the Summer.

\section{E. Discuss}

Based on previous research, celebrity endorser on Instagram consists of five indicators, there are trustworthiness, expertise, physical attractiveness, respect and similarity. Trustworthiness show integrity and confidence of an endorser [9]. In this indicator, author give two statement and the result are positive. So it can be said that endorser is able to influence consumer with their products bring to. Expertise show knowledge, experience and skills possessed endorser to be presented to the public [9]. There are three statements and respondent give a positive respond and agree. So endorser can influence respondent with the main attraction. Physical attractiveness is the most important, because company will choose endorser physically attractive [9]. Between two statements, respondent give positive respond to Celebgram. Respect is an indicator that indicates the quality of personal celebrity or endorser [9]. A statement field to respondents as many as two statements and respondents give a positive respond or agree with this statement, so it means Celebgram can give a good respect to respondents with their product bring to. Similarity is presented success rate of endorser in similarity with respondent characteristics, like gender, age, ethnicity, etc [9]. There are two statements in this indicator and respondent give a positive respond and agree if Celebgram have similarity about age and gender because respondents would prefer that have something in same with them. From five indicators, the best one and give more influence than other is physical attractiveness, because respondent will see from the physical advance. And after processing and analyze data from distributing questionnaires get scores 3906 which is interpreted on the continuum line high between $3740-4620$, while the ideal score for Celebgram is $\mathbf{5 5 0 0 .}$

Variable purchasing decision have four indicators, there are selection of product, selection of brand, selection of purchasing channel and the timing of purchases. Selection of product is step that consumer will choose product they want to buy [10] and the result from a statement is show that consumer will use a product that has value to them. Selection of brand is step that consumer must choose the brand that they want to use [10]. This indicator has two statements and the result is consumer give a positive opinion and every company have characteristic that different from another. Selection of purchasing channel is step that consumer must choose who is channel they want to come. Every consumer will have different opinion about this. From two statements, respondent give a positive opinion. The timing of purchases is step that when consumer will buy the product and it will be variation [10]. The result from two statements is consumer give positive 
opinion. From four indicators, one of indicator that has high score is selection of product, because consumer choose product from the function of them. After processing and analyze data, the scores is 2409 , that is in interval between 2380 - 2940 at the high category and ideal score for purchasing decision is 1100 .

Variable celebrity endorser on Instagram has positive influence on the purchase decision variable Walk in Summer. The effect of a positive means that any increase in the indicator variable occurs celebrity endorser on Instagram, there will be also an increase in the purchasing decision. It is appropriate previous research, that celebrity endorser on Instagram is the use of celebrities in an advertising on social media such as Facebook, Twitter and Instagram likely to have a positive impact for the company, because the products used endorser will be followed by the fans which would lead to the decision to buy the same product with a celebrity who became a favorite of fans are [12]. Based on the research that has been conducted by researchers at the consumers shoes Walk in Summer, the author can draw the conclusion that the influence between celebgram (celebrity endorser on Instagram) with Walk in the shoes purchasing decisions Summer is on a low correlation level.

\section{CONCLUSION}

Based on theoretical studies and research conducted by the author about the influence of Celebgram (celebrity endorser on Instagram) and online purchasing decision, the conclution are:

1. Overview of use Celebgram (celebrity endorser on Instagram) as a promotional media companies that are considered by consumers in this research is located in the high category. This is based on the criteria scores continuum line at the high category. The indicators used are indicators celebrity endorser of five indicators, namely trustworthiness, expertise, physical attractiveness, respect, and similarity [9]. Indicators contained in the variable Celebgram (celebrity endorser on Instagram) in this research consists of indicators that contribute to high and low by consumers Shoe Walk in Summer, is as follows:

a. Indicators of physical attractiveness is an indicator that contributes the highest to variable celebgram (celebrity endorser on Instagram) because it has the largest average scores, because the physical appearance celebgram owned by the consumer response has been to attract consumers to see the product used motivated because they want to have products that are similar to those used by the celebgram.

b. Indicators respect is an indicator that the lowest contribute to variable celebgram (celebrity endorser on Instagram) because it has the lowest average score, because the level of care that owned a celebgram according to consumer response has not been able to meet consumer desires concern for the environment is also a place to promote the product.
Other indicators that influence is expertise, similarity, and trustworthiness. The result of the acquisition the average score is not much different between the indicators, provides results conclusion that consumer responses shoes Walk in Summer to variable celebgram (celebrity endorser on Instagram) is positive to promote products Shoe Walk in Summer.

2. Overview of purchasing decisions are judged by consumers at the high category. It is based on the score criteria in the continuum line at the high category. Indicators studied are based on four indicators, namely the selection of products, brand selection, selection of distribution channels and the timing of purchases [10]. Indicators contained in the purchase decision variable in this research consists of indicators contribute to high and low by consumers shoe Walk in Summer, is as follows:

a. Indicators of product selection is an indicator that contributes the highest to the variable purchase decision because it has the largest average scores. This is because consumers choose products Walk in Summer shoes for functions held and also offers a variety of product design is simple yet comfortable and trendy.

b. Indicators of brand choice is an indicator that contributes most low variable purchase decision because it has the lowest average score. This is because consumers buy products not concerned with brands owned company that is not so widely known in the business world.

Other indicators that influence is the determination of the time of purchase and the purchase channel selection. Obtaining the average score differences were not so significant, indicate that consumer responses shoes Walk in Summer to variable purchase decision is positive.

3. Based on research by author on consumer shoe Walk in Summer, the conclution that the influence between Celebgram (celebrity endorser on Instagram) to online purchasing decision shoe Walk in Summer is $27,8 \%$, it means at a low level of correlation.

\section{SUGGESTION}

The author realizes that this research still has many limitations. Therefore, suggestions for further research are expected to conduct research on purchasing decisions by other competent factors strongly influence so that the company can always strive to improve the promotion, either through the media or not. It will also enrich knowledge on the management of marketing and consumer behavior as well as an input for the Walk in Summer to boost sales through promotion of good media strategy and also right. The rest, it would be interesting if further research was sharpened with a variable sponsorship, product design and also the price to influence purchasing decisions. The goal is to determine the effect of strength within the company and outside the company to the purchasing decision. 


\section{REFERENCES}

[1] APJII and Puskakom UI. Profil Pengguna Internet Indonesia 2014 [serial online]. Available from URL: http://www.slideshare. net/internetsehat/profil-pengguna-internet-indonesia-2014-riset-olehapjii-dan-puskakom-ui. Accessed December 15, 2015.

[2] Marketing. Transaksi Jual Beli Melalui Media Sosial [serial online]. Available from URL: http://www.marketing.co.id/transaksi-jual-belimelalui-mediasosial/. Accessed October 2, 2015.

[3] Techinasia. Jumlah Pengguna Instagram Indonesia [serial online]. Available from URL: https://id.techinasia.com/jumlah-penggunainstagram-indonesia. Accessed March 14, 2016.

[4] Detikcom. Capai 89 Persen, Indonesia Jadi Salah Satu Pengguna Instagram Terbanyak [serial online]. Available from URL: http://detikcom.xyz/capai-89persen-indonesia-jadi-salah-satu-penggunainstagram-terbanyak-wow-keren/. Accessed March 14, 2016.

[5] Jajakpendapat. Instagram User Behavior \#2 - Survey Report [serial online]. Available from URL: http://blog.jakpat.net/ instagramuserbehavior-2-surveyreport/. Accessed October 2, 2015.
[6] Maghfiroh, Lailatul dan Nurul Fitri. A Celebrification of Celebgram on Instagram: A Case Study of @Shireeenz. Allusion Vol. 04 No. 01, 2015.

[7] Kotler, Keller. Marketing Management. New Jersey: Pearson Education Inc; 2012, p.486, p.170, p.192.

[8] Putri Lestari, Desti. Analisis Strategi Internet Marketing Butik Online di Surabaya Melalui Instagram. Commononline Departemen Komunikasi Vol. 4 No. 2, 2015.

[9] Shimp, A Terence. Periklanan Promosi \& Aspek Tambahan Komunikasi Pemasaran. Terpadu, Jilid I ( edisi 5), Jakarta: Erlangga, 2007, pg. 304

[10] Kotler, Amstrong. Principle of Marketing. Global Edition (14 Edition). Pearson Education, 2012.

[11] Instagram. Available from URL: http://www.instagram.com. Accessed December 15, 2015.

[12] Foong, Lim Siew dan Rashad Yazdanifard. Celebrity Endorsement as a Marketing Tool. Global Journal of Management and Business Research: E- Marketing. Volu 14 Issue 4 Version 1.0, 2014. 